\title{
Corneal endothelial changes after posterior chamber intraocular lens implantation in patients with or without diabetes mellitus
}

\author{
Nanako Furuse, Seiji Hayasaka, Yukari Yamamoto, Tomoichi Setogawa
}

\begin{abstract}
We examined 96 patients (111 eyes) who underwent extracapsular cataract extraction with the implantation of a posterior chamber intraocular lens. Of 96 patients 24 (29 eyes) with non-insulin-dependent diabetes mellitus had no or simple retinopathy; 72 patients (82 eyes) served as non-diabetic controls. The central corneas of all subjects were photographed by a specular microscope preoperatively and three, six, and 12 months postoperatively. No significant differences in the endothelial cell density, coefficient of variation, or cell loss were noted between diabetic patients and age matched nondiabetic subjects during the observation period.
\end{abstract}

Extracapsular cataract extraction with the implantation of a posterior chamber intraocular lens provides excellent visual rehabilitation and has become the standard surgical approach. In the 1980 s many patients with diabetes mellitus also underwent these procedures. ${ }^{1}$

Defects in corneal endothelial cells may occur with age,${ }^{2}$ but the mean cell counts appear not to decline after the age of 50 years. ${ }^{3}$ Endothelial cell loss also occurs after intraocular lens implantation. ${ }^{48}$ Some investigators indicated that the diabetic endothelium is morphologically abnormal and may be at risk in any intraocular surgical procedure, ${ }^{9-11}$ while others showed no significant differences between diabetic and nondiabetic corneal endothelia. ${ }^{12-14}$

We therefore investigated whether or not the corneal endothelial cells after extracapsular cataract extraction with posterior chamber intraocular lens implantation in patients with diabetes mellitus differed from those in non-diabetic patients.

Department of

Dhimane

Medical University,

Izumo, Japan

N Furuse

S Hayasaka

Y Yamamoto

T Setogawa

Correspondence to: Nanako Furuse, MD, Department of Ophthalmology, Shimane Medical University, Izumo, Shimane 693, Japan.

Accepted for publication 4 January 1990

PATIENTS

We selected a total of 96 patients ( 111 eyes) who underwent extracapsular cataract extraction with posterior chamber intraocular lens implantation at Shimane Medical University Hospital between 1987 and 1988 and whose corneas were photographed by a specular microscope pre-
TABLE I Distribution of patients and eyes in present study

\begin{tabular}{lllcl}
\hline & & \multicolumn{3}{c}{ No. of patients (no. of eyes) } \\
\cline { 3 - 5 } Group & Age $(y r)$ & Non-diabetic & Diabetic & Total \\
\hline A & $52-59$ & $12(14)$ & $6(7)$ & $18(21)$ \\
B & $60-69$ & $26(27)$ & $7(8)$ & $33(35)$ \\
C & $70-79$ & $34(41)$ & $11(14)$ & $45(55)$ \\
A+B +C & & $72(82)$ & $24(29)$ & $96(111)$ \\
\hline
\end{tabular}

operatively and three, six, and 12 months postoperatively. The patients were classified as nondiabetic (72) and diabetic (24).

The diagnosis of diabetes mellitus was based on their blood glucose levels and the results of a glucose tolerance test in all subjects. The subjects were further divided into three groups according to age: group A, ages 52 to 59; group $B$, ages 60 to 69 ; and group $C$, ages 70 to 79 (Table I).

The 24 patients with non-insulin-dependent diabetes mellitus ranged in age from 52 to 79 years. The duration of diabetes mellitus in these patients ranged from two to 20 years: mean 8.9 (standard deviation 5.8 years). Their mean blood glucose level at the time of surgery was $7 \cdot 5$ (SD 1.6) $\mathrm{mmol} / \mathrm{l}$. Their haemoglobin A1 level was 9.9 (SD 1.8) g/dl. Six patients had been treated with diet only; 18 had been given oral drugs; and none was treated with insulin. Of 24 patients nine had no retinopathy and 15 had simple (background) retinopathy. None had been preoperatively treated with argon laser photocoagulation. Three, six, or 11 months after the cataract procedure and lens implantation seven patients with simple diabetic retinopathy received focal photocoagulation.

Excluded from the present study were those who wore contact lenses; patients with a previous history of ocular trauma or surgery, including preoperative photocoagulation; those with corneal disease, uveitis, glaucoma, and high myopia; and patients with operative and postoperative major complications such as posterior capsule thickening treated with neodymium: YAG laser.
SURGICAL PROCEDURE

The preoperative examination of the patients included a complete ophthalmic history and examination, medical examination, axial length 
A

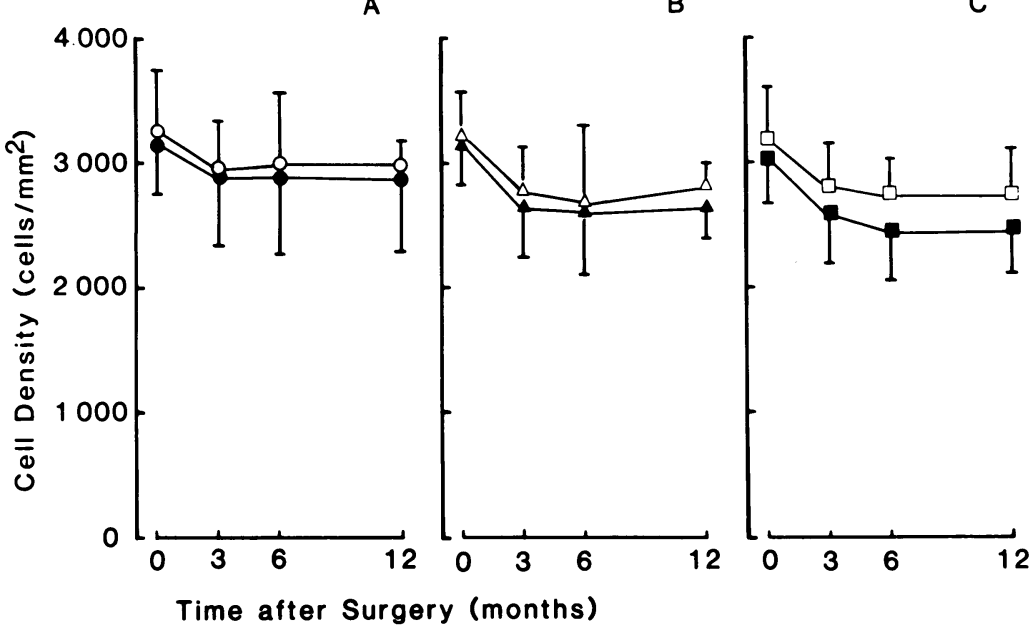

Figure 1: Cell density (cells/ $\mathrm{mm}^{2}$ ) in patient groups after surgery. Group A, ages 52 to 59; $B$, ages 60 to 69 ; and $C$, ages 70 to 79 years. $\bigcirc, \triangle$ $\square$, non-diabetics; $\mathbf{O}, \mathbf{\Delta}, \mathbf{\square}$ diabetics. Means and standard deviations are shown. measurements of the eye, and corneal endothelial photographs.

Each surgeon operated on a similar percentage of patients in the non-diabetic and diabetic groups.

The following surgical technique was standard for all patients. A fornix-based conjunctival flap and a limbal incision were made, followed by an anterior capsulotomy with use of a bent 25 -gauge needle. The nucleus was expressed, and cortical remnants were aspirated by means of an automated irrigation-aspiration instrument. After the capsular bag had been expanded with sodium hyaluronate instillation a modified C-loop or short C-loop posterior chamber intraocular lens was implanted in the capsule, sodium hyaluronate was aspirated, and an intracameral injection of acetylcholine was given. A peripheral iridectomy was made at the 11 or 1 o'clock position, and the wound was closed.

SPECULAR MICROSCOPY AND ANALYSIS

All eyes underwent clinical specular microscopy (Konan Keeler). At least five photographs were taken of the central corneal endothelium in each eye to be operated on. The endothelial photographs were magnified to 155 times, and cell outlines were traced.

Quantitative analysis was performed by a computer assisted morphometric analyser. We determined the cell density, the coefficient of variation of cell size (calculated from the standard deviation per mean value: polymegathism quotient), and cell loss from the preoperative value. Statistical analysis was by Student's $t$ test. A probability of $\mathrm{p}<0.05$ was considered statistically significant.

\section{Results}

The preoperative cell densities in the nondiabetic and diabetic subjects (Fig 1) were almost the same (about 3100 cells $/ \mathrm{mm}^{2}$ ) in the three age groups. The cell densities decreased to 2600 from 2900 cells $/ \mathrm{mm}^{2}$ three months after the operation and remained unchanged thereafter in all groups. A statistical comparison is shown in Table II. No significant differences in cell density were found between non-diabetic and diabetic subjects.

The coefficient of variation for all subjects is shown in Figure 2. The preoperative values in non-diabetic and diabetic patients were almost the same $(0.25$ to 0.28$)$ in all three age groups. No significant differences between non-diabetic and diabetic subjects were noted during the observation period (Table II).

10 to $20 \%$ of cells were lost during the three months after the operation (Fig 3), and the number of cells remained stationary thereafter. No significant differences in cell loss between non-diabetic and diabetic subjects were noted (Table II).

\section{Discussion}

We could find no statistically significant differences in corneal endothelial changes after extracapsular cataract extraction with posterior

TABLE II Statistical comparison of endothelial cell characteristics

\begin{tabular}{|c|c|c|c|c|c|c|c|c|c|c|c|c|}
\hline & \multicolumn{12}{|l|}{ p Value } \\
\hline & \multicolumn{4}{|c|}{ Group A (ages 52-59) } & \multicolumn{4}{|c|}{ Group B (ages 60-69) } & \multicolumn{4}{|c|}{ Group $C$ (ages (70-79) } \\
\hline & \multirow{2}{*}{$\begin{array}{l}\text { Before } \\
\text { surgery }\end{array}$} & \multicolumn{3}{|c|}{ After surgery } & \multirow{2}{*}{$\begin{array}{l}\text { Before } \\
\text { surgery }\end{array}$} & \multicolumn{3}{|c|}{ After surgery } & \multirow{2}{*}{$\begin{array}{l}\text { Before } \\
\text { surgery }\end{array}$} & \multicolumn{3}{|c|}{ After surgery } \\
\hline & & $3 m o$ & $6 m o$ & $12 \mathrm{mo}$ & & $3 m o$ & $6 m o$ & $12 \mathrm{mo}$ & & $3 m o$ & $6 m o$ & $12 \mathrm{mo}$ \\
\hline $\begin{array}{l}\text { Cell density } \\
\text { Non-diabetic } v \text { diabetic subjects } \\
\text { Non-diabetics }\end{array}$ & $\star$ & * & $\star$ & $\star$ & $\star$ & $\star$ & $\star$ & $\star$ & $\star$ & $\star$ & $\star$ & $\star$ \\
\hline compared with preoperative value & - & $\star \star$ & * & $\star$ & - & $\star \star \star$ & $\star \star \star$ & $\star \star \star$ & - & $\star \star \star$ & $\star \star \star$ & $\star \star \star$ \\
\hline $\begin{array}{l}\text { compared with 3-month value } \\
\text { Diabetics }\end{array}$ & - & - & * & $\star$ & - & - & $\star$ & $\star$ & - & - & $\star$ & $\star$ \\
\hline $\begin{array}{l}\text { compared with preoperative value } \\
\text { compared with } 3 \text {-month value }\end{array}$ & $\begin{array}{l}- \\
-\end{array}$ & $\begin{array}{l}\star \star \\
-\end{array}$ & $\star$ & ^ & $\begin{array}{l}- \\
-\end{array}$ & $\begin{array}{l}\star \star \\
-\end{array}$ & 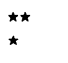 & 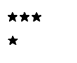 & - & $\begin{array}{l}\star \star \\
-\end{array}$ & 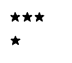 & 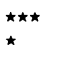 \\
\hline $\begin{array}{l}\text { Coefficient of variation } \\
\text { Non-diabetic } v \text { diabetic subjects } \\
\text { Non-diabetics }\end{array}$ & $\star$ & $\star$ & $\star$ & $\star$ & $\star$ & $\star$ & * & $\star$ & $\star$ & $\star$ & $\star$ & $\star$ \\
\hline $\begin{array}{l}\text { compared with preoperative value } \\
\text { Diabetics }\end{array}$ & - & $\star$ & $\star$ & $\star$ & - & * & ^ & $\star$ & - & $\star$ & $\star$ & 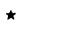 \\
\hline compared with preoperative value & - & $\star$ & $\star$ & $\star$ & - & $\star$ & $\star$ & $\star$ & - & $\star$ & $\star$ & $\star$ \\
\hline $\begin{array}{l}\text { Cell loss } \\
\text { Non-diabetic } v \text { diabetic subjects } \\
\text { Non-diabetics }\end{array}$ & - & * & $\star$ & $\star$ & $\dot{-}$ & * & * & $\star$ & - & $\star$ & $\star$ & ^ \\
\hline $\begin{array}{l}\text { compared with } 3 \text {-month value } \\
\text { Diabetics }\end{array}$ & - & - & $\star$ & * & - & - & $\star$ & $\star$ & - & - & $\star$ & $\star$ \\
\hline compared with 3 -month value & - & - & $\star$ & $\star$ & - & - & $\star$ & $\star$ & - & - & $\star$ & $\star$ \\
\hline
\end{tabular}




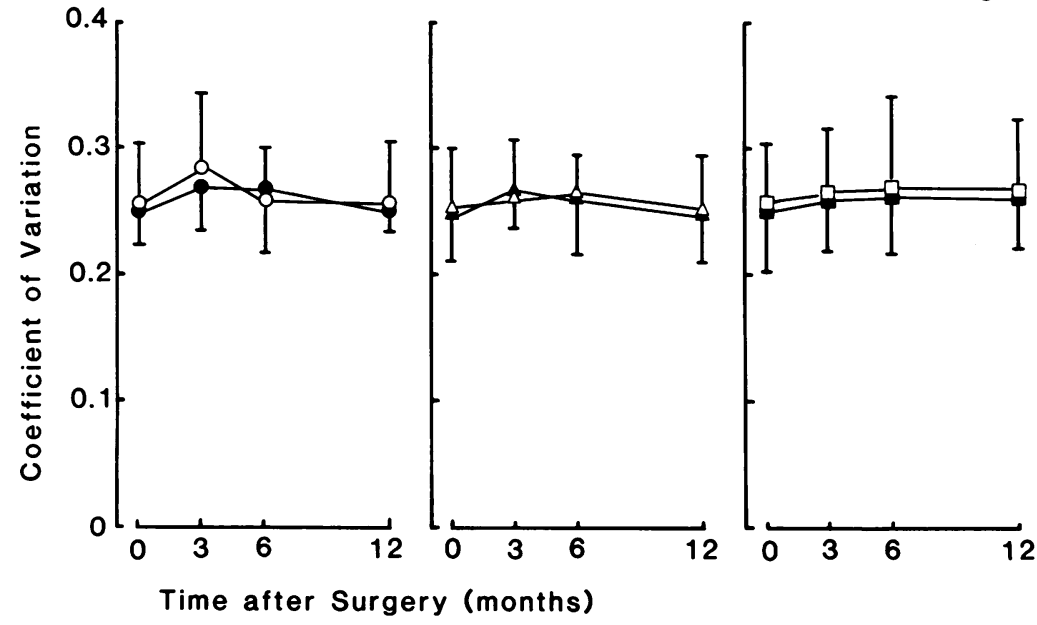

Figure 2: Coefficient of variation in patient groups after surgery. See legend to Figure 1.
A

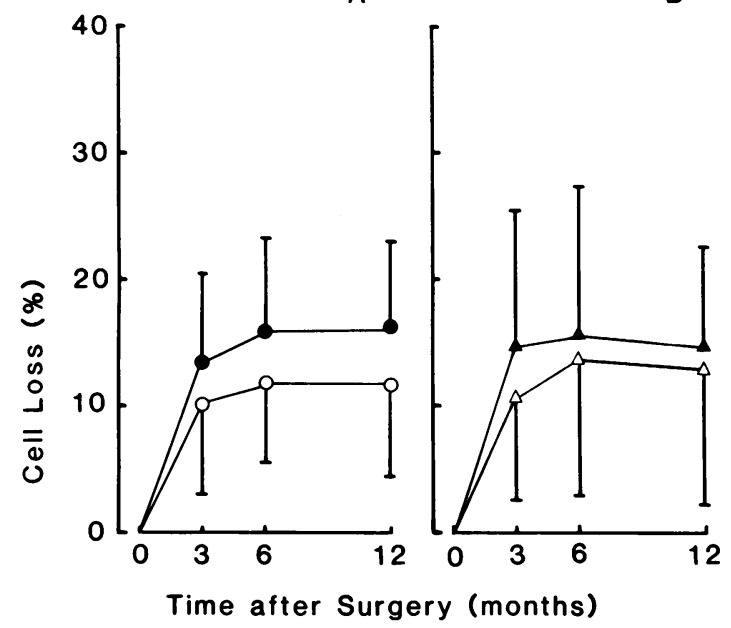

B

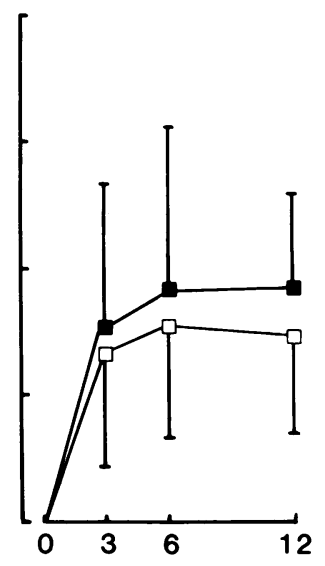

Figure 3: Cell loss (\%) in patient group after surgery. See legend to Figure 1.

chamber intraocular lens implantation between non-diabetic and diabetic patients.

The endothelial cell population is reported to change during life. ${ }^{2}$ In our present study, however, no significant differences were noted in the preoperative number of corneal endothelia of three groups of patients whose ages ranged from 52 to 79 years. The cell density at the central cornea preoperatively in the patients in the present study was about 3100 cells $/ \mathrm{mm}^{2}$. These values were slightly higher than those reported previously by other investigators. ${ }^{467910}$

It has been suggested that mechanical trauma at the time of surgery is the main cause of endothelial cell loss, with later loss possibly caused by uveitis. ${ }^{\text {is }}$ Schultz and associates ${ }^{8}$ and Galin and coworkers ${ }^{16}$ showed that central endothelial cell density stabilises approximately three months after uncomplicated intraocular surgery. Our results on the corneal endothelial changes following extracapsular cataract extraction with posterior chamber intraocular lens implantation were also similar to their findings.

Schultz et $a l,{ }^{9}$ Kamiya et $a l,{ }^{10}$ and Itoi et al ${ }^{11}$ reported the increased coefficient of variation, or polymegathism, in diabetic endothelial cells. In our present study, however, no differences in coefficient of variation were noted between diabetic and non-diabetic eyes. Our findings were similar to those of Lass $e a^{a l^{13}}$ and Shetlar $e t$ $a l,{ }^{1+}$ who found no differences in coefficient of variation between diabetic and non-diabetic patients. Although the exact explanation for the discrepancy is difficult to determine, one possible reason may be that the difference in diabetic conditions, particularly blood glucose levels and duration of disease, were different in the patients among the various investigations. Another possibility may have been a damaging effect of photocoagulation on the corneal endothelium, though the effect is uncertain. We therefore excluded patients with a preoperative history of photocoagulation from the present study.

From our present findings we believe that all corneas in patients with diabetes may not be at risk in extracapsular cataract extraction with posterior chamber lens implantation.

1 Sebestyen JG. Intraocular lenses and diabetes mellitus. Am $\mathcal{F}$ Ophthalmol 1986; 101: 425-8.

2 Laule A, Cable MK, Hoffman CE, Hanna C. Endothelial cell population changes of human cornea during life. Arch Ophthalmol 1978; 96: 2031-5.

3 Wilson RS, Roper-Hall MJ. Effect of age on the endothelia cell count in the normal eye. $B r \mathcal{F}$ Ophthalmol 1982; 66 : 513-5.

4 Rao G, Stevens RE, Harris JK, Aquavella JV. Long-term changes in corneal endothelium following intraocular lens implantation. Ophthalmology 1981; 88: 386-97.

5 Kraff MC, Sanders DR, Lieberman HL. Monitoring for continuing endothelial cell loss with cataract extraction and intraocular lens implantation. Ophthalmology 1982; 89: intraocul.

6 Azen SP, Hurt A, Steel D, et al. Effects of the Shearing posterior chamber intraocular lens on the corneal endothelium. Am f Ophthalmol 1983; 95: 798-802.

7 Liesegang TJ, Bourne WM, Ilstrup DM. Short- and long-term endothelial cell loss associated with cataract extraction and intraocular lens implantation. Am $\mathcal{F}$ Ophthalmol 1984; 97 32-9.

8 Schultz RO, Glasser DB, Matsuda M, Yee RW, Edelhauser HF. Response of the corneal endothelium to catarac surgery. Arch Ophthalmol 1986; 104: 1164-9.

9 Schultz RO, Matsuda M, Yee RW, Edelhauser HF, Schultz $\mathrm{KJ}$. Corneal endothelial changes in type I and type II diabetes mellitus. Am f Ophthalmol 1984; 98: 401-10.

10 Kamiya I, Nagahara K, Kohzuka T, Kubota K. Corneal endothelial changes following intraocular lens implantation in diabetic subjects (in Japanese). Rinsho Ganka 1988; 42: in diabetic $581-4$.

11 Itoi M, Nakamura T, Mizobe K, Kodama Y, Nakagawa N, Itoi $M$. Specular microscopic studies of the corneal endothelium of Japanese diabetics. Cornea 1989; 8: 2-6.

12 Straatsma BR, Pettit TH, Wheeler N, Miyamasu W. Diabetes mellitus and intraocular lens implantation. Ophthalmology 1983; 90: 336-43.

13 Lass JH, Spurney RV, Dutt RM, et al. A morphologic and fluorophotometric analysis of the corneal endothelium in type I diabetes mellitus and cystic fibrosis. Am $\mathcal{F}$ Ophthalmol 1985; 100: 783-8.

14 Shetlar DJ, Bourne WM, Campbell RJ. Morphologic evaluation of Descemet's membrane and corneal endothelium in tion of Descemet's membrane and corneal endoth
diabetes mellitus. Ophthalmology 1989; 96: 247-50.

15 Galin MA, Chowchuvech E, Turkish L. Uveitis and intraocular lenses. Trans Ophthalmol Soc UK 1976; 96: 166-7.

16 Galin MA, Lin LL, Fetherolf E, Obstbaum SA, Sugar A Time analysis of corneal endothelial cell density after cataract extraction. Am $\mathcal{F}$ Ophthalmol 1979; 88: 93-6. 